Original article

\title{
A year-round investigation of indoor airborne fungi in Croatia
}

\author{
Daniela Jakšić Despot and Maja Šegvić Klarić \\ Department of Microbiology, Faculty of Pharmacy and Biochemistry, University of Zagreb, Croatia \\ Received in December 2013 \\ CrossChecked in December 2013 \\ Accepted in April 2014
}

\begin{abstract}
This study assessed the composition of aeromycota at a grain mill and four dwellings (two apartments and two basements) as well as in outdoor air during one year in Zagreb, Croatia. The incidence of Aspergilli from sections Flavi, Nigri, and Versicolores was also assessed. Airborne fungi were collected using an air-sampler and DG-18 agar plates. The average concentrations of airborne fungi in the grain mill ranged from 14,310 to $40,000 \mathrm{cfu} \mathrm{m}^{-3}$, which was above the hazardous level $\left(10^{4} \mathrm{cfu} \mathrm{m}^{-3}\right)$, whereas the values statistically estimated using Feller's correction were up to six times higher. Concentrations in the apartment (163-1244 $\left.\mathrm{cfu} \mathrm{m}^{-3}\right)$ were lower than in outdoor air (286-2090 $\left.\mathrm{cfu} \mathrm{m}^{-3}\right)$ and lower than in the basement (697-1203 $\left.\mathrm{cfu} \mathrm{m}^{-3}\right)$, except in the warmer period of the year when they were similar. The most abundant species throughout the year were Cladosporium spp. (90-100\%), Penicillium spp. (40-100\%), and Alternaria spp. (10-100\%), which are common for temperate climates. Aspergilli from the Flavi (50$100 \%$ ) and Nigri (15-40 \%) sections as well as A. ochraceus (15-60 \%) and Eurotium spp. (85-100 \%) were the most abundant at the grain mill and were rarely found in outdoor air. In the basement, Aspergilli (Versicolores) were more abundant than in the apartment. The excess of aeromycoparticles in the grain mill throughout the year may have represented a serious health risk to mill workers. This is the first Croatian one-year study of indoor airborne fungi in a grain mill and dwellings; however monitoring should continue over a longer period.
\end{abstract}

KEY WORDS: Flavi; grain mill; Nigri; residential areas; Versicolores

Many studies have recently investigated the levels of airborne fungi in indoor environments and their role in the initiation and/or progression of chronic respiratory diseases like asthma and chronic rhinosinusitis (1-6). In addition, the European Environment Agency (EEA) has published a report on air quality in Europe in 2012 (7), where the most severe health effects were attributed to air pollution by particulate matter (PM). The highest mortality caused by PM clearly stems from particle fractions $2.5 \mu \mathrm{m}$ in diameter, which represents $40-80 \%$ of PM mass concentration in ambient air in Europe. Fungal spores are regularly found in outdoor and indoor air as part of PM. Their size ranges usually from 1 to $10 \mu \mathrm{m}$ with variations even among the same species. Besides fungal spores, fragments of mycellium may also be released in the air with sizes even smaller than fungal spores (8-10). Inhalation of these particles represents a threat to human health due to possible deposition in the lower respiratory system and interactions with lung tissue. No uniformness in the suggested guidelines for acceptable levels of fungi in indoor environments has yet been achieved and there is no dose-response relationship between the concentration of airborne fungi and adverse health effects. Moreover, the immunocompetence of an 
exposed individual plays a crucial role in both the type and intensity of possible effects.

Airborne fungi are of special concern in industrial environments such as grain mills or agricultural warehouses, where their concentration may be up to a hundred thousand times higher than in outdoor air. It has been suggested that occupational concentrations of airborne fungi above $10^{4} \mathrm{cfu} \mathrm{m}^{-3}$ should be considered a health hazard in non-sensitized subjects, although this does not mean that such a working environment will necessarily lead to any respiratory symptoms (9-13). Considering the limited number of studies addressed at the fungal burden in occupational environments and urban homes in our country, the aim of the present study was to investigate the composition and concentration of aeromycota in industrial and residential environments in Zagreb, Croatia, for which purpose measurements were performed in a grain mill, an apartment and a basement.

Special attention was paid to the occurrence of Aspergilli from sections Flavi, Nigri, and Versicolores for several reasons. In immunocompromised patients, most invasive respiratory infections are caused by Aspergillus fumigatus, A. flavus, A. terreus, and $A$. niger sensu lato $(14,15)$. Aspergillus flavus and $A$. parasiticus from the Flavi section are important producers of the highly toxic and carcinogenic aflatoxin B1 and these species grow on almost all crops (16). Aspergillus versicolor is the most frequently reported Versicolores fungus from damp indoor environments and its presence might be related to Sick Building Syndrome (17-20). Moreover, it represents a special threat for human health due to its very small spores and release of mycellium fragments (10) as well as ability to produce sterigmatocystin $(21,22)$. Finally, Aspergillus section Nigri, or black aspergilli, which can easily be isolated from occupational and residential environments, have been reported to produce ochratoxins and fumonisins (23).

This is the first quantitative and qualitative assessment of indoor airborne fungi in a grain mill and dwellings over a one-year period in Croatia.

\section{MATERIALS AND METHODS}

\section{Sampling and determination of airborne fungi}

Airborne fungi were collected over a one-year period (2012) in two-month intervals at a grain mill
(GM) situated near Zagreb, Croatia, and in residential locations which included two apartments (AP) and two basements (BS). The differences between the chosen apartments and basements were considered irrelevant for this study. Samples of outdoor air (ODA) were also collected. The floor area of the APs was approximately $70 \mathrm{~m}^{2}$ each, both inhabited and without visible mould growth. The BS's were situated in the same dwellings as the APs. These were unoccupied and served as a repository for the inhabitants. Visible mould growth as well as typical mouldy odour was observed in both basements. The GM was situated in an industrial area $40 \mathrm{~km}$ outside Zagreb and served for processing cereals, mainly corn and wheat, as well for short-term flour storage. It was organised as a building consisting of a big reception and depository at the ground floor, milling site located at the first floor, and sieving site located at the second floor. The air was quite saturated with grain particles, but no mouldy odour was observed. Samplings were done in the middle of the working week in the morning during the most intensive and constant milling operations at 20 locations, including site of grain/flour exchange, site of flour storage, site of sieving, and site of milling. Twenty samples were taken from the APs at locations: kitchen, dining room, living room, bedroom, and bathroom. Samples were also taken from 10 locations in the BS, two at each site. The total number of samples was 420 . Air temperature $\left({ }^{\circ} \mathrm{C}\right)$ and relative humidity $(\%)$ were measured by thermo-hygrometer (Boneco, Widnau, Switzerland) at every location during each sampling. Fungi were sampled $1 \mathrm{~m}$ above ground using a Mas 100 Eco air sampler (Merck, Darmstadt, Germany) with 400 holes (hole to agar impactor) and dichlorane $18 \%$ glycerol agar (DG-18) plates (25). The impaction velocity of the sampler was approximately $10.8 \mathrm{~m} \mathrm{~s}^{-1}$ and airflow rate $100 \mathrm{~L} \mathrm{~min}^{-1}$. Because of the high contamination level, a volume of $10 \mathrm{~L}$ (sampling time $6 \mathrm{~s}$ ) was chosen for sampling in the GM, while $50 \mathrm{~L} \mathrm{~min}^{-1}$ (sampling time $30 \mathrm{~s}$ ) was applied at the other sampling locations. After field sampling, the plates were incubated for 5 days at $25 \pm 2{ }^{\circ} \mathrm{C}$, after which the developed fungal colonies were counted. The concentrations of airborne fungi were expressed as colony forming units (cfu) per volume of air sampled (expressed in cubic meter), i.e. cfu $\mathrm{m}^{-3}$. Feller's correction (probable statistical total) was applied to all of the samples (24). The airborne fungi were identified on the basis of their macro- and microscopic characteristics after subculturing on Czapek, Malt Extract and Potato Dextrose agar (Fluka, 
Sigma-Aldrich, Steinheim, Germany), according to the manuals $(25,26)$. In order to separate the aspergilli of interest, they were isolated on Czapek Yeast Agar [CYA, (26)] and Malt Extract Agar (MEA; Becton Dickinson, MD, USA) and incubated at $25{ }^{\circ} \mathrm{C}$ in the dark for seven days (Aspergillus section Flavi and section Nigri) and ten to fourteen days for Aspergillus section Versicolores. The identification of Aspergillus species was conducted according to Pitt and Hocking (25) and de Hoog et al. (26).

\section{Statistics}

Concentrations of airborne fungi at each location are represented as mean $\pm \mathrm{SD}$ of $\mathrm{cfu} \mathrm{m}^{-3}$. For each plate, Feller's correction (probable statistical total) was applied - as the number of viable particles impinged on a plate increases, the probability of the next particle going into an "empty hole" decreases. The probable number of viable particles calculated from Feller's formula $(\mathrm{Pr}=\mathrm{N} 1 / \mathrm{N}+1 / \mathrm{N}-1+1 / \mathrm{N}-2+1 / \mathrm{N}-\mathrm{r}+1)$, given by the manufacturer (Merck KgaA, Darmstadt, Germany; $\mathrm{Pr}=$ probable statistical total; $r=$ Number of cfu counted; $\mathrm{N}=$ total number of holes in the sampling head).

The Kolmogorov-Smirnov test was used to verify whether the variables were normally distributed. Concentrations of airborne fungi were logarithmically transformed to normalise distribution. When normality was achieved, ANOVA and Tukey multiple comparison tests were used. Otherwise, Kruskal-Wallis test was applied, followed by Dunn's multiple comparison test. Spearman's correlation coefficients between average fungal concentrations at each location and ambient parameters (temperature and relative humidity) were also calculated.

\section{RESULTS AND DISCUSSION}

Data related to average concentrations of airborne fungi ( $\mathrm{cfu} \mathrm{m}^{-3}$ ) and average temperature and relative humidity specific for each sampling site and each period of year are presented in Table 1. Levels of aeromycota in the GM (up to $40,000 \mathrm{cfu} \mathrm{m}^{-3}$ ) were significantly higher during the whole year than at the other sampling sites $(p<0.0001)$. Statistically corrected concentrations at the GM were up to 6 times higher than the measured values. Compared to observations from studies on similar occupational environments such as another grain mill [max. concentration
$1.7 \times 10^{4} \mathrm{cfu} \mathrm{m}^{-3}(27)$ ], rice mill [mean $13.71 \times 10^{3}$ $\left.48.42 \times 10^{3} \mathrm{cfu} \mathrm{m}^{-3} ;(28)\right]$, outdoor agricultural area [mean 72-1796 $\mathrm{cfu} \mathrm{m}^{-3}$; (29)], agricultural non-point source during wheat harvesting season [mean $10^{5}$ $10^{6} \mathrm{cfu} \mathrm{m}^{-3} ;(30)$ ], or sawmills (mean 1700-7300 $\mathrm{cfu} \mathrm{m}^{-3}$; (13)] our analysis showed an overload with airborne fungi in the GM throughout the entire year. Taking into account statistically estimated values (up to $2.6 \times 10^{5} \mathrm{cfu} \mathrm{m}^{-3}$ ), levels of airborne fungi in the GM were 20 times higher than the occupational concentration of airborne fungi considered hazard to human health $\left(>10,000 \mathrm{cfu} \mathrm{m}^{-3}\right)$. Variations of airborne fungi levels in the GM showed no correlation to both temperature and relative humidity (Table 2). This was not surprising because the measured levels were the result of fungal contamination of grains that developed during storage, before delivery to the GM.

Seasonal variations of airborne fungi in the AP and $\mathrm{BS}$ did not exhibit a similar pattern. In the BS, airborne fungi exceeded $1000 \mathrm{cfu} \mathrm{m}^{-3}$ from May to November while the levels in January, March, September, and November were significantly higher as compared to the AP $(p<0.001)$. Variations of airborne fungi levels in the BS also did not show a correlation to temperature and relative humidity (Table 2 ). Taken together, these observations suggest a more pronounced fungal contamination in the BS probably due to poor maintenance and ventilation.

Seasonal variations of airborne fungi levels in the AP and ODA showed a similar pattern and positively correlated to temperature changes $(\mathrm{R}=0.6661$, $\mathrm{R}=0.5409$ ) but not to relative humidity. However, the levels of aeromycota in the AP obtained in January, March, July, and September were significantly lower than in ODA $(p<0.001)$.

The observed concentrations of fungi in ODA (240-2090 $\left.\mathrm{cfu} \mathrm{m}^{-3}\right)$ were twice as high as the concentrations observed in similar investigation conducted in 2002/03 in Austria [100-1000 $\mathrm{cfu} \mathrm{m}^{-3}$; (31)]. In that same investigation, apartments without visible mould growth had a maximum of fungal spore concentration of $300 \mathrm{cfu} \mathrm{m}^{-3}$. The highest observed concentration in the AP from our investigation was 13 times higher $\left(4000 \mathrm{cfu} \mathrm{m}^{-3}\right)$ and more than 16 times higher $\left(5060 \mathrm{cfu} \mathrm{m}^{-3}\right)$ in the BS. Our previous yearround investigation, which was also performed in 2002/03, at outdoor air locations in Zagreb (32) showed that airborne fungi peaked in August and September (up to $400 \mathrm{cfu} \mathrm{m}^{-3}$ ), which was five times lower than the levels measured in that same period in this study. Since Zagreb and the Austrian region 


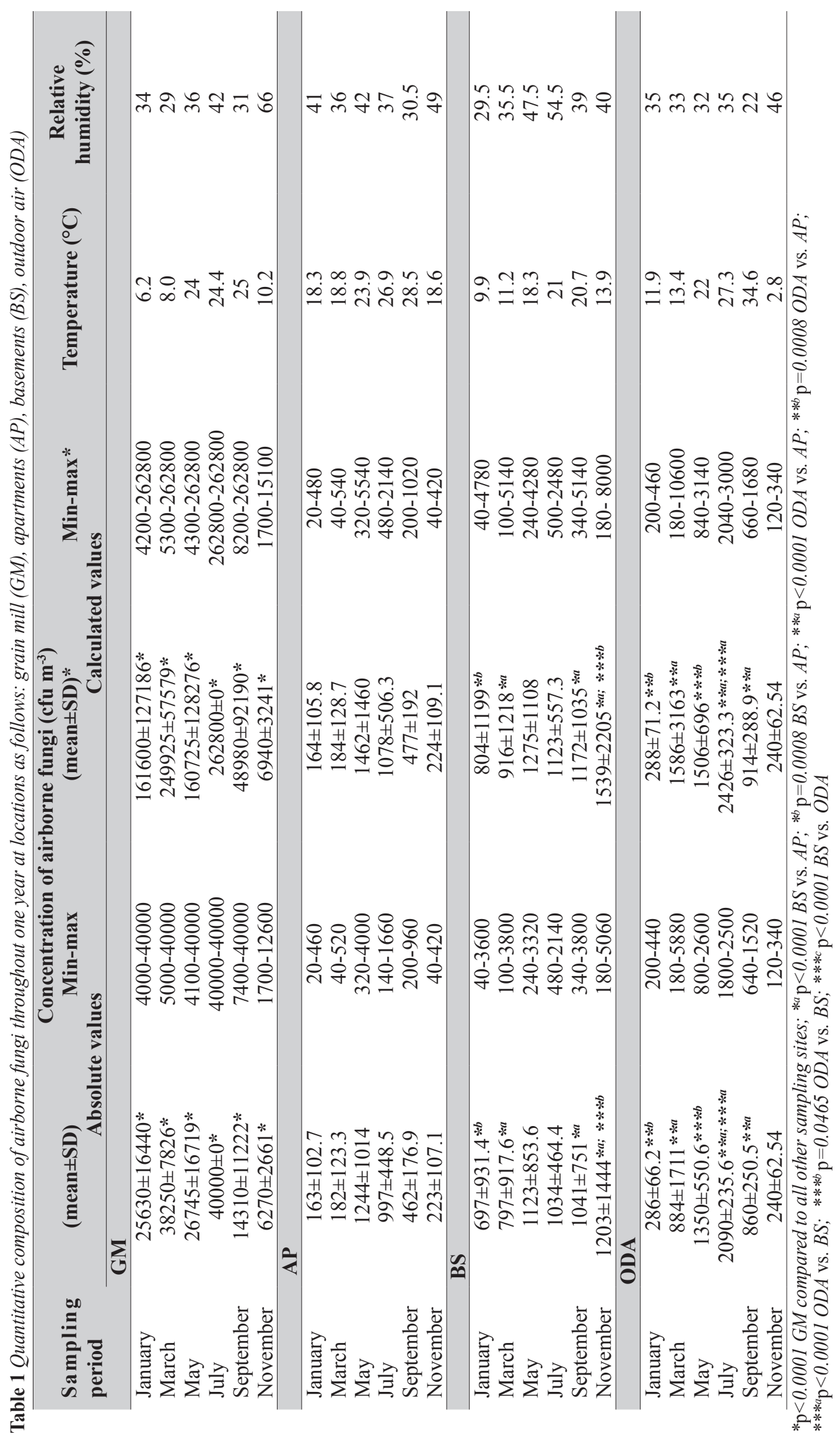


Table 2 Correlation between concentration of airborne fungi $\left(c f u m^{-3}\right)$, temperature, and relative humidity

\begin{tabular}{ccccccccc}
\hline Sampling site & \multicolumn{2}{c}{ Grain mill } & \multicolumn{2}{c}{ Apartments } & \multicolumn{2}{c}{ Basements } & \multicolumn{2}{c}{ Outdoor air } \\
Parameter & T ( $\left(^{\circ}\right)$ & rh (\%) & T ( $\left(^{\circ}\right)$ & rh (\%) & T ( $\left(^{\circ}\right)$ & rh (\%) & T ( $\left(^{\circ}\right)$ & rh (\%) \\
\hline$p$-value (two-tailed) & 0.8998 & 0.2336 & 0.0476 & 0.8479 & 0.2309 & 0.1730 & 0.0957 & 0.6215 \\
R square & 0.0045 & 0.3295 & $0.6661^{*}$ & 0.01035 & 0.3325 & 0.4068 & 0.5409 & 0.06659 \\
\hline
\end{tabular}

T-temperature

rh-relative humidity

${ }^{*} \mathrm{p}<0.05$ significant positive correlation

investigated in the previously mentioned study are in the same climate zone, we can speculate that the higher levels of airborne fungi in ODA and in the AP and BS in this study could be related to current climate changes. However, the sample size and number of locations prevent us from reaching a firm conclusion.

The qualitative composition of airborne fungi at each site and in each sampling period is presented in Table 3. The qualitative composition of airborne fungi in the GM differed from the other sampling locations. The most dominant species in the GM belonged to Aspergillus spp. and Eurotium spp. (85-100 \%).The most prevalent fungal genera in the residential areas were similar to those in ODA: Cladosporium spp (45$100 \%$ in AP and $55-95 \%$ in BS), Penicillium spp. (85-100 \% in AP and $70-100 \%$ in BS), and Aspergillus spp. (20-80 \% in AP and 50-95 \% in BS).

High frequencies of Aspergillus spp., Eurotium spp., Cladosporium spp., Penicillium spp. and Alternaria spp. at places where people live and work raises concern because all of them have proven to be causative agents for fungal allergies and other respiratory disorders $(27,33)$. Aspergilli of interest (sections Flavi, Nigri, and Versicolores) were frequent only at certain locations. We did not specify any species from these sections because the applied methods were sufficient only for sectional classifications. Due to morphological similarities among species from each section, specific DNA sequence data is required $(16,34-38)$.

Species belonging to section Flavi were very frequent in the GM (50-100\%) and present throughout the year. The sampled plates after incubation sometimes revealed overgrowth by these species, indicating a very high concentration of their viable conidia in the air. Eurotim spp. was also dominantly present in the GM (90-100\% samples) throughout the year and their mycellia usually covered the entire plate. Black aspergilli were isolated from GM samples and the peak was observed in May (55\%). As for the other mould genera, Cladosporium spp. was frequent in GM samples (60-95 \%) followed by Wallemia spp. (40-90 \%), Ulocladium spp. (5-80 \%), and Alternaria spp. (5-10\%). Our failure to isolate the aforementioned species from samples taken in certain periods may have been due to overgrowth by section Flavi and/or Eurotium species.

We can also speculate on the observed frequencies of section Versicolores isolates. These species are known for their very small conidia (around $3 \mu \mathrm{m}$ ) and even if sampling is successful, their growth is too slow which causes them to become overwhelmed by other species. Despite this, we occasionally succeeded in isolating these species from GM samples (5-40 \%). Versicolores species reached their peak in November, which was probably due to the fact that other airborne fungi were at their lowest concentrations. Considering the very high concentration of airborne fungi in the GM, exposed workers are under risk. Moreover, due to the enormous amount of fungi belonging to section Flavi, there is the possibility of toxigenic strains and consequently aflatoxin B1 (AFB1). Recently it has been proven that black aspergilli are able to produce fumonisins in high quantities (23). Consequently these mycotoxins might be inhaled through grain and flour dust or via conidia of black aspergilli. Well-known producers of fumonisins belong to the genus Fusarium and they are present in high amounts at places where maize is processed and stored (26). Because Fusarium spp. conidia are not likely to be airborne, we managed to isolate these species only in September $(10 \%)$. However, the presence of Fusarium spp. is expected throughout the year and so is the presence of fumonisins in maize.

Significant differences have been observed in the composition of aeromycota in residences compared to ODA. Sometimes, plates taken in the BS were overwhelmed in growth by Aspergillus section Versicolores. This indicated drastic fungal contamination with these species at particular sites, since a frequency of $A$. versicolor above $20 \%$ is considered an indicator of indoor fungal contamination 

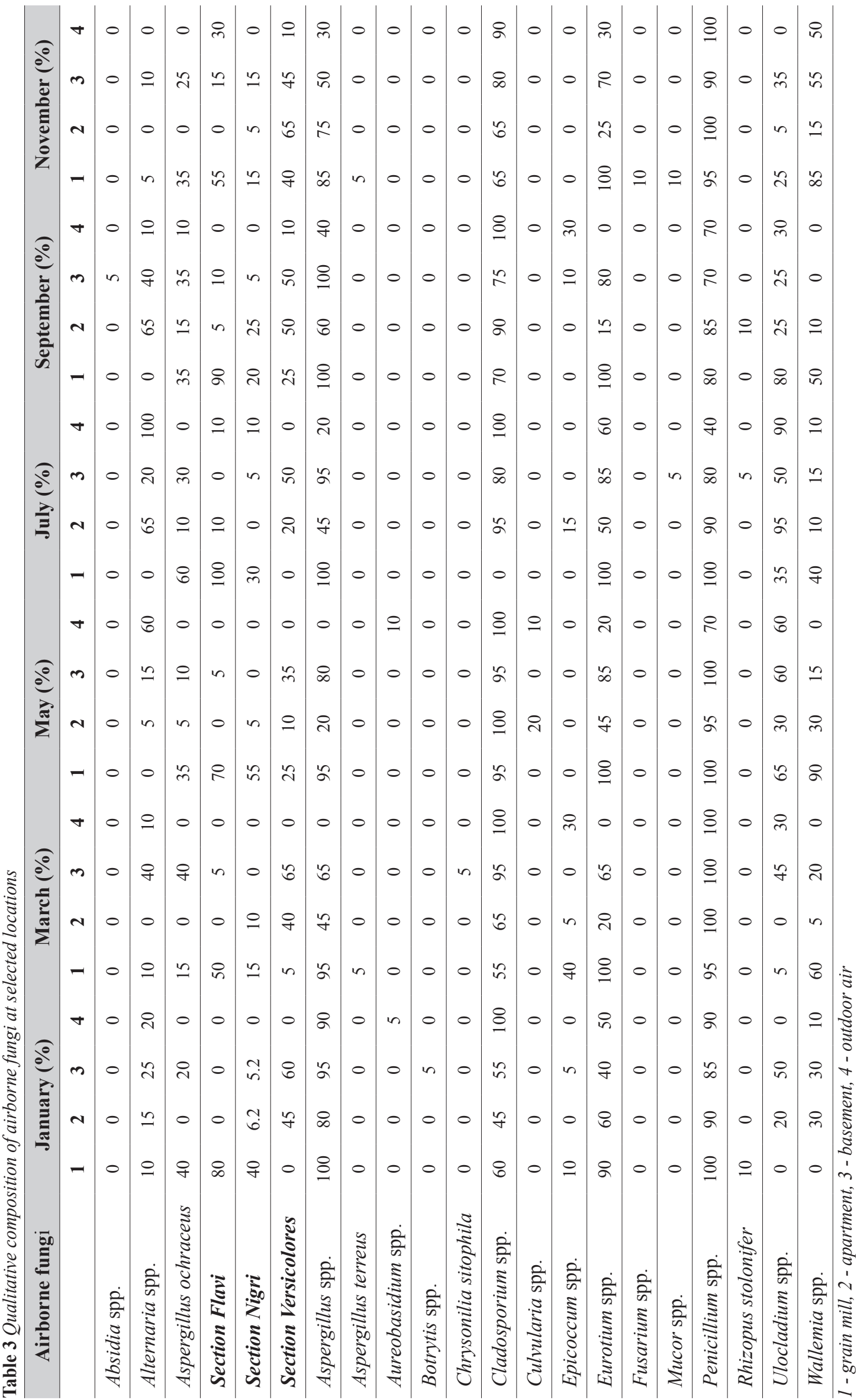
(21). One of the mould sources in the air of indoor environments is damp building material. Aspergillus species are often found on substrates such as walls of residentces and working interiors, where their survival depends only on water activity $\left(\mathrm{a}_{\mathrm{w}}\right)$. Aspergilli are primary colonizers and can be customized to $\mathrm{a}_{\mathrm{w}}$ values below 0.8 , which allows them to succeed in damp indoor environments more likely than other moulds $(22,39)$. Aspergillus versicolor is the most frequently reported fungal species in section Versicolores from damp indoor environments and its presence might be related to Sick Building Syndrome (17-20). Recent publications based on the molecular identification of Aspergillus species (Versicolores) indicated that Aspergillus versicolor sensu stricto were not common in buildings. However, it has also been reported that Aspergilli from this section isolated from indoor air are highly diverse in temperate regions (36), so we cannot exclude the presence of $A$. versicolor sensu stricto in our isolates. Considering the variety of recently identified Aspergillus species from this section (36), it is likely that more than one was able to produce sterigmatocystin. Therefore, their presence in high concentrations in indoor air could represent a serious threat to human health. Samples from the AP did not indicate overgrowth by these species, although their presence was persistent. Relative humidity measured at the AP in periods when indoor spaces are heated (January, November) ranged from 41 to $49 \%$ and a high rate of condensation on windows was observed. In that same period, the ambient temperature was $18.3-18.6^{\circ} \mathrm{C}$ and these conditions were considered supportive for sporulation and mycotoxin production by $A$. versicolor (40).

\section{CONCLUSIONS}

Considering the observed and analysed data, there is a threat of chronic exposure to secondary metabolites (sterigmatocystin, fumonisin, and aflatoxin). These metabolites can accumulate in spores and mycellium fragments in unknown concentrations. When people are exposed to high concentrations of mycotoxins, especially from contaminated food, one can reasonably easily establish a connection with a certain disease. However, when they are present in very low concentrations, it is very difficult to study and evaluate their effects. Moreover, there are many unknown facts about these effects when inhalation is the primary means of exposure. However, there is a remarkable amount of studies proving toxic, mutagenic, and carcinogenic properties of mould secondary metabolites on respiratory surrogate tissues, cell lines, and animal respiratory system, as well as case-reports addressing adverse health effects in humans (4, 41-46). Therefore, monitoring of airborne fungi in occupational as well as living environments is of great importance in the prevention of unfavourable effects on human health.

\section{Acknowledgements}

The study was done within the scientific project No.006-0061117-1242, financially supported by the Ministry of Science, Education and Sports of Republic of Croatia.

\section{Conflict of interest}

The authors declare that they have no conflict of interest.

\section{REFERENCES}

1. Ahn BH, Park YH, Shin SH. Mouse model of Aspergillus and Alternaria induced rhinosinusitis. Auris Nasus Larynx 2009;36:422-6. doi: 10.1016/j.anl.2008.08.009

2. Bush RK, Portnoy JM. The role and abatement of fungal allergens in allergic diseases. J Allergy Clin Immunol 2001;107(Suppl 3):S430-40. doi: 10.1067/mai.2001.113669

3. Douwes J, Pearce N. Invited commentary: is indoor mould exposure a risk factor for asthma? Am J Epidemiol 2003;158:203-6. doi: 10.1093/aje/kwg149

4. Orlandi RR, Marple BF. Fungus and chronic rhinosinusitis: weighing the evidence. Otolaryngol Head Neck Surg 2010;143:611-3. doi: 10.1016/j.otohns.2010.07.002

5. Shin SH, Ponikau JU, Sherris DA, Congdon D, Frigas E, Homburger HA, Swanson MC, Gleich GJ, Kita H. Chronic rhinosinusitis: An enhanced immune response to ubiquitous airborne fungi. J Allergy Clin Immunol 2004;114:1369-75. doi: 10.1016/j.jaci.2004.08.012

6. Thompson GR 3rd, Patterson TF. Fungal disease of the nose and paranasal sinuses. J Allergy Clin Immu 2012;129:321-6. doi: 10.1016/j.jaci.2011.11.039

7. European Environment Agency (EEA). Air Quality in Europe - Report No 4/2012. Copenhagen: EEA; 2012.

8. Fröhlich-Nowoisky J, Pickersgill DA, Després VR, Pöschla U. High diversity of fungi in air particulate matter. Proc Natl Acad Sci USA 2009;106:12814-9. doi: 10.1073/ pnas.0811003106

9. Eduard W. Fungal spores: A critical review of the toxicological and epidemiological evidence as a basis for occupational exposure limit setting. Crit Rev Toxicol 2009;39:799-864. doi: 10.3109/10408440903307333

10. Cabral JP. Can we use indoor fungi as bioindicators of indoor air quality? Historical perspectives and open questions. Sci 
Total Environ 2010;408:4285-95. doi: $10.1016 / \mathrm{j}$. scitotenv.2010.07.005

11. Kuhn DM, Ghannoum MA. Indoor mold, toxigenic fungi, and Stachybotrys chartarum: infectious disease perspective. Clin Microbiol Rev 2003;16:144-72. doi: 10.1128/ CMR.16.1.144-172.2003

12. Opplinger A, Rusca S, Charrière N, Duc TV, Droz PO. Assessment of bioaerosols and inhalable dust exposure in Swiss sawmills. Ann Occup Hyg 2005;49:385-91. PMID: 15699057

13. Šegvić Klarić M, Varnai VM, Ljubičić Čalušić A, Macan J. Occupational exposure to airborne fungi in two Croatian sawmills and atopy in exposed workers. Ann Agric Environ Med 2012;19:205-11. PMID: 22742790

14. Klich MA. Health effects of Aspergillus in food and air. Toxicol Ind Health 2009;25:657-67. doi: $10.1177 / 0748233709348271$

15. Krishnan S, Manavathu EK, Chandrasekar H. Aspergillus flavus: an emerging non-fumigatus Aspergillus species of significance. Mycoses 2009;52:206-22. doi: 10.1111/j.1439-0507.2008.01642.x

16. Varga J, Frisvad JC, Samson RA. Two new aflatoxin producing species, and an overview of Aspergillus section Flavi. Stud Mycol 2011;69:57-80. doi: 10.3114/ sim.2011.69.05

17. Nielsen KF, Thrane U, Larsen TO, Nielsen PA, Gravesen S. Production of mycotoxins on artificially inoculated building materials. Int Biodeter Biodegr 1998;42:9-16. doi: 10.1016/ S0964-8305(98)00038-9

18. Piecková $E$ and Jesenská Z. Microscopic fungi in dwellings and their health implications in humans. Ann Agric Environ Med 1999;6:1-11. PMID: 10384209

19. Tuomi T, Reijula K, Johnsson T, Hemminki K, Hintikka EL, Lindroos O, Kalso S, Koukila-Kähkölä P, MussaloRauhamaa H, Haahtela T. Mycotoxins in crude building materials from water-damaged buildings. Appl Environ Microbiol 2000;66:1899-904. PMID: 10788357

20. Jussila J, Komulainen H, Kosma VM, Nevalainen A, Pelkonen J, Hirvonen MR. Spores of Aspergillus versicolor isolated from indoor air of a moisture-damaged building provoke acute inflammation in mouse lungs. Inhal Toxicol 2002;14:1261-77. doi: $10.1080 / 08958370290084908$

21. Engelhart S, Loock A, Skutlarek D, Sagunski H, Lommel A, Färber H, Exner M. Occurrence of toxigenic Aspergillus versicolor isolates and sterigmatocystin in carpet dust from damp indoor environments. Appl Environ Microbiol 2002;68:3886-90. doi:10.1128/AEM.68.8.3886-3890.2002.

22. Nielsen KF. Mycotoxin production by indoor molds. Fungal Genet Biol 2003;39:103-17. PMID: 12781669

23. Varga J, Kocsubé S, Suri K, Szigeti Gy, Szekeres A, Varga M, Tóth B, Bartók T. Fumonisin contamination and fumonisin producing black Aspergilli in dried vine fruits of different origin. Int J Food Microbiol 2010;143:143-9. doi: 10.1016/j.ijfoodmicro.2010.08.008

24. Feller W. An Introduction to the Probability Theory and Its Application. New York: John Wiley and Sons Inc; 1950.

25. Pitt JI, Hocking AD. Fungi and Food Spoilage. New York (NY): Springer Science+Business Media LLC; 2009.

26. de Hoog GS, Guarro J, Gene J, Figueras MJ. Atlas of Clinical Fungi. $2^{\text {nd }}$ ed. Utrecht: Centraalbureau voor Schimmelcultures/ Reus: Universitat Rovira i Virgili; 2000.
27. Lugauskas A, Krikštaponis A, Šveistyte L. Airborne fungi in industrial environments- potential agents of respiratory diseases. Ann Agric Environ Med 2004;11:19-25. PMID: 15236494

28. Desai MR, Ghosh SK. Occupational exposure to airborne fungi among rice mill workers with special reference to aflatoxin producing A. flavus strains. Ann Agric Environ Med 2003;10:159-62. PMID: 14677906

29. Adhikari A, Sen MM, Gupta-Bhattacharya S, Chanda S. Airborne viable, non-viable, and allergenic fungi in a rural agricultural area of India: a 2-year study at five outdoor sampling stations. Sci Total Environ 2004;326:123-41. doi: 10.1016/j.scitotenv.2003.12.007

30. Hameed AAA, Khodr MI. Suspended particulates and bioaerosols emitted from an agricultural non-point source. J Environ Monit 2001;3:206-9. doi:10.1039/b007159p.

31. Haas D, Habib J, Galler H, Buzina W, Schlacher R, Marth E, Reinthaler FF. Assessment of indoor air in Austrian apartments with and without visible mold growth. J Atmos Environ 2007;41:5192-201. doi:10.1016/j. atmosenv.2006.07.062

32. Šegvić Klarić M, Pepeljnjak S. A year-round aeromycological study in Zagreb area, Croatia. Ann Agric Environ Med 2006;13:55-64. PMID: 16841873

33. Ljubičić Ćalušić A, Varnai VM, Čavlović AO, Šegvić Klarić M, Beljo R, Prester LJ, Macan J. Respiratory health and breath condensate acidity in sawmill workers. Int Arch Occup Environ Health 2013;86:815-25. doi:10.1007/s00420-012-0817-x

34. Samson RA, Noonim P, Meijer M, Houbraken J, Frisvad JC, Varga J. Diagnostic tools to identify black Aspergilli. Stud Mycol 2007;59:129-45. doi: 10.3114/sim.2007.59.13.

35. Godet M, Munaut F. Molecular strategy for identification in Aspergillus section Flavi. FEMS Microbiol Lett 2010;304:15768. doi: 10.1111/j.1574-6968.2009.01890.x

36. Jurjević Ž, Peterson SW, Horn BW. Aspergillus section Versicolores: nine new species and multilocus DNA sequence based phylogeny. IMA Fungus 2012;3:59-79. doi: 10.5598/ imafungus.2012.03.01.07

37. Jurjević Ž, Peterson SW, Stea G, Solfrizzo M, Varga J, Hubka $\mathrm{V}$, Perrone G. Two novel species of Aspergillus section Nigri from indoor air. IMA Fungus 2012;3:159-73. doi: 10.5598/ imafungus.2012.03.02.08.

38. Nielsen KF, Mogensen JM, Johansen M, Larsen TO, Frisvad JC. Review of secondary metabolites and mycotoxins from the Aspergillus niger group. Anal Bioanal Chem 2009;395:1225-42. doi: 10.1007/s00216-009-3081-5

39. Schulz T, Senkpiel K, Ohgke H. Comparision of the toxicity of reference mycotoxins and spore extracts of common indoor moulds. Int J Hyg Environ Health 2004;207:267-77. doi: 10.1078/1438-4639-00282

40. Vujanović V, Smoragiewicz W, Krzysztyniak K. Airborne fungal ecological niche determination as one of the possibilities for indirect mycotoxin risk assessment in indoor air. Environ Toxicol 2001;16:1-8. PMID: 11345539

41. May JJ, Stallones L, Darrow D, Pratt DS. Organic dust toxicity (pulmonary mycotoxicosis) associated with silo unloading. Thorax 1986;41:919-23. PMID: 3590053

42. Straus DC. Molds, mycotoxins, and sick building syndrome. Toxicol Ind Health 2009;25:617-35. doi: $10.1177 / 0748233709348287$ 
43. Piecková E, Wilkins K. Airway toxicity of house dust and its fungal composition. Ann Agric Environ Med 2004;11:67-73. PMID: 15236501

44. Piecková E. Adverse health effects of indoor moulds. Arh Hig Rada Toksikol 2012;63:545-59. doi: 10.2478/10004-1254-632012-2221.

45. Jakab GJ, Hmieleski RR, Zarba A, Hemenway DR, Groopman JD. Respiratory aflatoxicosis: suppression of pulmonary and systemic host defenses in rats and mice. Toxicol Appl Pharmacol 1994;125:198-205. PMID: 8171428

46. Kelman BJ, Robbins CA, Swenson LJ, Hardin BD. Risk from inhaled mycotoxins in indoor office and residential environments. Int J Toxicol 2004;23:3-10. doi: $10.1080 / 10915810490265423$ 


\title{
Sažetak
}

\section{Jednogodišnje istraživanje razine plijesni u zraku unutarnjih prostora}

Cilj rada bio je ispitati varijacije učestalosti (\%) i koncentracija $\left(\mathrm{cfu} \mathrm{m}^{-3}\right)$ plijesni u zraku mlina žitarica i četiriju stambenih prostora (dva stana i dva podruma) u odnosu na vanjski zrak tijekom jedne godine $\mathrm{u}$ Zagrebu (Hrvatska). Učestalost Aspergillus vrsta iz sekcija Flavi, Nigri i Versicolores također je ispitana. Plijesni iz zraka su uzorkovane pomoću uređaja Air-sampler MAS 100 Eco u kojem su postavljene DG18-agarske ploče. Prosječna koncentracija aerogenih plijesni u mlinu bila je između 14.310 i $40.000 \mathrm{cfu} \mathrm{m}^{-3}$, što je veće od koncentracije $\left(10^{4} \mathrm{cfu}^{-3}\right)$ koja se smatra opasnom za zdravlje. Procijenjene vrijednosti koncentracija plijesni u zraku mlina, dobivene Felerovom korekcijom, čak su šest puta veće od izmjerenih koncentracija. U stanovima (163-1244 $\mathrm{cfu} \mathrm{m}^{-3}$ ) koncentracije aerogenih plijesni bile su manje nego u vanjskom zraku (286-2090 $\left.\mathrm{cfu} \mathrm{m}^{-3}\right)$ i podrumima (697-1203 $\left.\mathrm{cfu} \mathrm{m}^{-3}\right)$, izuzev u toplijim mjesecima kada su izmjerene vrijednosti bile slične. Tijekom godine dominirale su vrste iz rodova Cladosporium spp. (90-100 \%), Penicillium spp. (40-100 \%), i Alternaria spp. (10-100 \%), koje su uobičajene u područjima s umjerenom klimom. Aspergile iz sekcija Flavi (50-100 \%) i Nigri (15-40 \%), A. ochraceus (15-60 \%) i Eurotium spp. (85-100 \%) dominirali su u zraku mlina, a u uzorcima vanjskog zraka rijetko su detektirane. Vrste Aspergillus iz sekcije Versicolores s većom učestalošću nađene u podrumima nego u stanovima. Veliko opterećenje mlina aerogenim plijesnima tijekom cijele godine može biti opasno za zdravlje radnika. Ujedno, ovo je prvo jednogodišnje ispitivanje sezonske varijabilnosti u sastavu plijesni u zraku mlina žitarica i stambenih prostora u Hrvatskoj. Međutim, monitoring treba nastaviti tijekom dužeg razdoblja.

KLJUČNE RIJEČI: Flavi; mlin; Nigri; stambeni objekti; Versicolores

\section{CORRESPONDING AUTHOR:}

\author{
Maja Šegvić Klarić \\ Department of Microbiology, Faculty of Pharmacy and Biochemistry \\ University of Zagreb, Croatia \\ E-maiI:msegvic@pharma.hr
}

